\title{
The Effect of Classroom Management on Students' Mathematics Learning Motivation
}

\author{
Millah Novita, Rusdi \\ Institut Agama Islam Negeri Bukittinggi \\ millahnovita11@gmail.com
}

\begin{abstract}
This study was motivated by students' low motivation to learn mathematics in a twelfth-grade natural science group at one of the senior high schools in West Sumatra, Indonesia. One of the alleged contributing factors is the less conducive classroom atmosphere due to the ineffectiveness of the applied classroom management. This study aims to determine the effect of classroom management on students' mathematics learning motivation. This study was correlational research with the ex post facto nature of research. The study population was the twelfth-grade natural science group at one of the senior high schools in West Sumatra, Indonesia, which consisted of five groups. The data collection technique used was a questionnaire. Samples were taken by non-probability sampling with the purposive sampling technique. The data were analyzed using simple linear regression analysis. The results indicated a correlation between classroom management variables and mathematics learning motivation with a reasonably strong category. Based on the result, it can be concluded that there is a significant effect of classroom management on the students' mathematics learning motivation.
\end{abstract}

Keywords: Classroom Management, Learning Motivation, Mathematics Learning

\section{INTRODUCTION}

Education is an important aspect and cannot be separated from human life. Education is an effort to obtain knowledge. Mathematics plays an important role in education. It is one of the most important disciplines to be studied in school. Due to the importance of learning mathematics in life and the education world, mathematics can generally be heard with the parable that mathematics is the queen and servant of knowledge (Siagian, 2017).

The success determinant in learning mathematics is one of the teachers' tasks in schools, as the importance of learning mathematics in life is known. Sudjana explained that learning is essentially a process of regulating and organizing the environment around students to grow and encourage students to carry out the learning process (Mahmud \& Idham, 2017). Therefore, teachers must be able to foster student motivation in learning mathematics.

Motivation means the basic drive that moves a person to get into a process and maintain his behavior until he achieves his goals. While learning, motivation is an urge to move, direct and maintain someone's behavior to act and do something when studying until achieving the learning goals (Susanti, 2019). Motivation is a very large asset and is needed in learning. Motivation is closely related to the needs of students (Pratiwi et al., 2019). Students will act quickly if there is a need in them. Thus, it can be concluded that students who are motivated to learn will be enthusiastic and active in learning. On the contrary, not motivated students will be lazy to learn.

There are three functions of motivation is encourage people to do means as the stimulus of every activity that is carried out, guiding the direction of action, means that motivation can provide 
direction and activities carried out according to their goals, and selecting actions, which means determining and choosing what activities must be done in accordance with the objectives (Suharni \& Purwanti, 2018).

Moreover, the indicators of learning motivation according to Uno are, There is an eagerness and desire to succeed, There is encouragement and need in learning, There are hopes and ambitions for the future, There is appreciation in learning, There are interesting activities in learning, and The existence of a conducive learning environment (Sidik \& Sobandi, 2018).

According to Uno, learning motivation can arise due to intrinsic and extrinsic factors. Intrinsic factors are in the form of desire, the eagerness to succeed, the encouragement of learning needs, and expectations of their goals. In contrast, the extrinsic factors are awards, a conducive learning environment, and interesting learning activities (Nasrah \& Muafiah, 2020). So, optimal student learning motivation apart from the students can also arise due to encouragement from other people and a supportive environment. This extrinsic motivation can arise from the encouragement or treatment of a teacher.

Teachers are the most important factor in guiding and increasing students' motivation to learn. Moreover, there must be an effort made by a teacher to make students have the motivation to learn. The efforts made are related to classroom management carried out by teachers while teaching. So, to make students motivated in learning, the teacher must apply good and effective classroom management. Management comes from the English words administration, leadership, and supervision. So class supervision can also be called class management. Jones and Jones state that motivating students is a key aspect of effective classroom management (Sunu \& Arya, 2015).

Teachers are the main actor in the learning process. The teacher's ability to manage the classroom is very important because it allows many things to happen (Hidayat et al., 2020). Classroom management skills are the basis for facilitating a conducive classroom atmosphere. If the teacher cannot manage the class, the class atmosphere will become noisy, which causes many students were also disturbed (Kurni \& Susanto, 2018).

Classroom management is an activity carried out, so that class conditions in teaching and learning activities are fun, orderly, disciplined and increase students' desire to learn optimally. In addition, class management also means all efforts directed to create an effective and fun learning atmosphere and can motivate students well (Astuti, 2019). One of the classroom management's goals is to motivate students to develop their behavior following learning objectives (Rahma \& Dara, 2017). One of the classroom management's benefits is increasing student enthusiasm and motivation (Setiaji, 2019). Based on some statements above, it can be concluded that effective classroom management can make students motivated in learning.

The indicators of classroom management are, 1) The teacher arranges the seats according to the characteristics of the students and subjects, as well as the learning activities that will be carried out, 2) The volume and intonation of the teacher's voice in the learning process must be heard well by students, 3) The teacher's words are polite and can be understood by students, 4) The teacher adapts the learning material to the speed and learning ability of students, 5) The teacher creates order, discipline, comfort, safety, and decision on regulations in carrying out the learning process, 6) The teacher provides reinforcement and feedback on the responses and learning outcomes of students during the learning process, 7) The teacher respects the opinions of students, 8) The teacher wears polite, clean and neat clothes, 9) At the beginning of each semester, the teacher conveys the syllabus of the subjects he teaches, 10) The teacher starts and ends the learning process according 
to the scheduled time. The teacher must implement these indicators well so that learning motivation is good (Haerena, 2016).

To find out the initial description of class management and students' motivation to learn mathematics in the twelfth grade of natural science group at one of the senior high schools in West Sumatra, Indonesia, the researchers conducted a field survey in the form of observations and interviews in the period of February-April 2021. The class observations obtained information that students' motivation to learn mathematics was still low. It was indicated that students were less active in learning, there was no visible desire to master mathematics, and students have not shown learning mathematics as a necessity. Concerning classroom management, several problems were found like the teacher has not practiced varied skills in teaching, The teacher has not created a conducive classroom atmosphere because there were still many students who talk while studying, The teacher did not make rules such as a sanction if there were students who play with handphones, joke around in learning. The teacher only reprimanded students for a while. Then some students would do it again. The teacher took too long to convey certain material even though it seemed that all students had already understood it, and The teacher did not arrange student seats. The interviews with several students obtained information that students think mathematics is difficult. They are less interested in mathematics. Interviews with teachers stated that the low motivation of students to take part in learning was marked by not being ready to take part in learning and being passive in receiving lessons.

Some related studies on a literature review about the relationship between classroom management and learning motivation of elementary school students concluded that classroom management has a relationship and influences student motivation in elementary schools. When the teacher's skills can arouse the interest and enthusiasm of students to follow the lesson, the student's learning motivation will appear. It means that the teacher's skills in managing the classroom determine whether the learning in the classroom runs effectively or vice versa (Rizki \& Noviardilla, 2021). There was also a study on the relationship between classroom management and student motivation in social studies subjects for class III at SDN Blukbuk 1 Tangerang Regency. The results showed that the teacher carried out a positive and significant relationship between classroom management by arranging student seats and paying attention to students' classmates so that students felt comfortable in the classroom with increased student learning motivation due to changes in students with increasing student grades. The magnitude of the relationship is indicated by a correlation value of $r_{\mathrm{xy}}=0.084$, which means that there is a very strong relationship (Sunardin, 2020). Next, the study on classroom management in improving the learning process used qualitative descriptive methods concluded that the classroom management strategy carried out by the teacher was conditioning students to be ready to learn in class, learn to concentrate, use appropriate and varied methods and use media according to the material (Nugraha, 2018).

Based on the description described above, the researcher is interested in finding out more about classroom management and students' motivation to learn mathematics. The purpose of this study is to answer the following questions, 1) to find out the relationship between classroom management and students' mathematics learning motivation, 2) to find out how strong is the relationship between classroom management and students' mathematics learning motivation, 3) to find out the significant effect of classroom management on students' mathematics learning motivation, 4) to find out the effect of classroom management has on students' mathematics learning motivation. 


\section{METHOD}

The type of this study was correlational research, which was to determine the level of relationship between two or more variables without making changes, additions, or manipulations to the existing data. The nature of this study was ex post facto because of events that have occurred in the past, then trace back to find out the factors that can cause these events.

The population in this study was students of the twelfth grade of the natural science group at one of the senior high schools in West Sumatra, Indonesia, which consisted of five classes. The sampling technique was carried out by non-probability sampling with the purposive sampling technique. The purposive sampling technique was used because not all samples had criteria that matched the phenomenon under the study. The criteria used as research samples were students from classes who get mathematics learning from the same teacher. The students sampled in this study were students of twelfth natural science four class and twelfth natural science five class from teacher B there are 61 students. The population-based on purposive sampling is shown in Table 1.

Table 1. Population-Based on Purposive Sampling

\begin{tabular}{cccl}
\hline No & Group & $\begin{array}{c}\text { The Number of } \\
\text { Students }\end{array}$ & The Teacher \\
\hline $\mathbf{1}$ & Sciense Group 1 & 34 & Teacher A \\
\hline $\mathbf{2}$ & Sciense Group 2 & 35 & \multirow{2}{*}{ Teacher B } \\
\hline $\mathbf{3}$ & Sciense Group 3 & 36 & \\
\hline $\mathbf{4}$ & Sciense Group 4 & 31 & \\
\hline $\mathbf{5}$ & Sciense Group 5 & 30 & \\
\hline & Total & 166 & \\
\hline
\end{tabular}

The variables in this study were classroom management as the independent variable $(X)$ and students' motivation to learn mathematics as the dependent variable $(\mathrm{Y})$. Based on the research variables, there were two instruments, namely, a classroom management questionnaire and a students' mathematics learning motivation questionnaire. The questionnaire was prepared using a Likert scale with five options, namely always, often, sometimes, rarely, and never. Questionnaire items were stated in the form of positive and negative statements with scores, as shown in Table 2.

Table 2. Classroom Management and Learning Motivation Questionnaire Item Scores

\begin{tabular}{ccc}
\hline Options & Positive Statement & Negative Statement \\
\hline Always & 5 & 1 \\
\hline Often & 4 & 2 \\
\hline Sometimes & 3 & 3 \\
\hline Rarely & 2 & 4 \\
\hline Never & 1 & 5 \\
\hline
\end{tabular}

Experts validated both instruments before being used to obtain a valid instrument. Instrument validation relates to aspects of format, content, and language. The validation results of the two instruments by three experts obtained an average value of 3.7 or $74 \%$ with a valid category.

According to the expert, the constructively valid questionnaire was then tested before being used. The questionnaire test was carried out in the twelfth grade of natural science non-sample at one of the senior high schools in West Sumatra, Indonesia, to see the validity and reliability of the questionnaire empirically. The questionnaire validity test of using product-moment correlation. The validity test results showed that from 39 classroom management questionnaire items, 24 valid questionnaire items were obtained, while for the student's mathematics learning motivation 
questionnaire, 16 useful items were obtained from 20 items. Furthermore, the empirically valid questionnaire items were tested for reliability. The reliability test of the questionnaire used Cronbach's Alfa technique. The results of the reliability test, for the classroom management questionnaire obtained the value of rcount $=0.887>$ rtable $=0.361$ or $0.887>0.361$, while for the students' mathematics learning motivation questionnaire, the value of rcount $=0.903>$ rtable $=$ 0.361. These results indicated that both questionnaires were reliable with a very high category.

Furthermore, the data analysis technique in this study used inferential statistical methods with simple linear regression analysis techniques. To perform a simple linear regression analysis, the analysis prerequisite test was first carried out in the form of a normality test and a linearity test. Class management data were analyzed using the percentage formula as shown in Table 3.

Table 3. Class Management Category (Haryani, 2020)

\begin{tabular}{cc}
\hline $\begin{array}{c}\text { Class Management } \\
\text { Percentage }\end{array}$ & Criteria \\
\hline $91-100$ & Very Good \\
\hline $81-90$ & Good \\
\hline $71-80$ & Enough \\
\hline $61-70$ & Less \\
\hline$\leq 60$ & Very Less \\
\hline
\end{tabular}

While, learning motivation data were also analyzed using the percentage formula as shown in Table 4.

Table 4. Category of Learning Motivation

\begin{tabular}{cc}
\hline $\begin{array}{c}\text { Percentage of Learning } \\
\text { Motivation }\end{array}$ & Criteria \\
\hline$<20.00$ & Very low motivation \\
\hline $21.00-40.00$ & Low motivation \\
\hline $41.00-60.00$ & Enough motivation \\
\hline $61.00-80.00$ & High motivation \\
\hline $81.00-100$ & Very high motivation \\
\hline
\end{tabular}

\section{FINDINGS}

\section{Class Management}

The data analysis results of class management according to class management indicators are as shown in Table 5.

Table 5. Analysis of Each Class Management Indicator

\begin{tabular}{|c|c|c|c|}
\hline No. & Class Management Indicators & Percentage & Category \\
\hline 1. & $\begin{array}{l}\text { The teacher arranges the seats according to the characteristics of the } \\
\text { students and subjects, as well as the learning activities that will be } \\
\text { carried out. }\end{array}$ & $84.43 \%$ & Good \\
\hline 2. & $\begin{array}{l}\text { The volume and intonation of the teacher's voice in the learning } \\
\text { process must be heard well by students. }\end{array}$ & $81.42 \%$ & Good \\
\hline 3. & The teacher's words are polite and can be understood by students. & $76.23 \%$ & Enough \\
\hline 4. & $\begin{array}{l}\text { The teacher adapts the subject matter to the speed and learning ability } \\
\text { of students. }\end{array}$ & $76.72 \%$ & Enough \\
\hline 5. & $\begin{array}{l}\text { The teacher creates order, discipline, comfort, safety, and decisions } \\
\text { on regulations in carrying out the learning process. }\end{array}$ & $82.89 \%$ & Good \\
\hline
\end{tabular}




\begin{tabular}{clcc}
\hline No. & Class Management Indicators & Percentage & Category \\
\hline $\mathbf{6 .}$ & $\begin{array}{l}\text { The teacher provides reinforcement and feedback on the responses } \\
\text { and learning outcomes of students during the learning process. }\end{array}$ & $80.49 \%$ & Good \\
\hline 7. & Teachers respect students' opinions. & $80.49 \%$ & Good \\
\hline $\mathbf{8 .}$ & The teacher wears polite, clean and neat clothes. & $86.07 \%$ & Good \\
\hline $\mathbf{9 .}$ & $\begin{array}{l}\text { At the beginning of each semester, the teacher conveys the syllabus } \\
\text { of the subjects he teaches. }\end{array}$ & $81.97 \%$ & Good \\
\hline 10. & $\begin{array}{l}\text { The teacher starts and ends the learning process according to the } \\
\text { scheduled time. }\end{array}$ & $77.54 \%$ & Enough \\
\hline
\end{tabular}

\section{Students' Mathematics Learning Motivation}

The analysis results of students' motivation to learn mathematics according to indicators of learning motivation are as shown in Table 6.

Table 6. Each Indicator Analysis of Learning Motivation

\begin{tabular}{lcl}
\multicolumn{1}{c}{ Indicators of learning motivation } & Percentage & Category \\
\hline There is an eagerness and desire to succeed & $71.80 \%$ & High motivation \\
\hline There is an encouragement and a need for learning & $77.49 \%$ & High motivation \\
\hline There are hopes and ambitions for the future & $78.85 \%$ & High motivation \\
\hline There is an appreciation in learning & $76.23 \%$ & High motivation \\
\hline There are interesting activities in learning & $75.30 \%$ & High motivation \\
\hline There is a conducive learning environment & $71.15 \%$ & High motivation \\
\hline
\end{tabular}

Based on the results of the prerequisite test, namely the normality test of class management data, obtained the value of Lcount $=0.095$ and Ltable $=0.113$ or Lcount $<$ Ltable, which means the data is normally distributed. At the same time, the data analysis of learning motivation obtained the value of Lcount $=0.097$ and Ltable $=0.113$ or Lcount $<$ Ltable means the data is normally distributed. Furthermore, the linearity test obtained Farithmetic $=23,234$ and Ftable $=4.00$ or Farithmetic $>$ Ftable, which means the data has a linear pattern.

Based on the results of data analysis, the correlation coefficient value in this study was obtained $\mathrm{r}_{\mathrm{xy}}=0.532$ with a coefficient of $28.3024 \%$. The regression equation was $\mathrm{Y}=24.260+$ $0.553 \mathrm{X}$. While the regression significance test obtained a $\mathrm{t}_{\text {count }}$ value of 4.82 and a $\mathrm{t}_{\text {table }}=2.001$. Based on the results of the data analysis, the correlation coefficient value obtained $r_{x y}=0.532$. The amount of $r_{x y}$ between class management variables and students' motivation to learn mathematics is sufficient. While the coefficient of determination based on the analysis results was obtained of $28.3024 \%$, meaning that class management contributed $28.3024 \%$ to students' motivation to learn mathematics while other factors influenced the rest.

\section{DISCUSSION}

\section{Classroom Management}

Classroom management involves the teacher's role in managing the class to make students learn well and achieve educational goals. The ability to manage the teaching and learning process well will create a situation that allows children to learn to be a starting point for teaching success. Students can learn in a natural atmosphere, without pressure, and in a stimulating learning environment. Classroom management activities aim to create and maintain a class atmosphere (condition) so that teaching activities can run effectively and efficiently. The role of a teacher in 
classroom management is very important, especially in creating interesting learning. It is because, in principle, the teacher has the task of managing the class (Erwinsyah, 2017). In addition to the principles of classroom management, namely, enthusiastic, warm, and friendly teacher attitudes, challenging learning, learning variations, flexibility in every teacher's actions, emphasizing positive things, and inculcating student discipline. By implementing classroom management, learning becomes more conducive, effective, and efficient (Pujiman et al., 2021).

The actualization of the classroom management process is manifested in the behavior of teachers in the classroom, which encourages the growth of a conducive and productive classroom climate. Teacher behavior in learning that can technically affect the realization of the climate includes six types of behavior: 1) responsiveness, 2) ability to share attention, 3) ability to focus group attention, 4) ability to give clear instructions, 5) ability to provide reinforcement, and 6) the ability to give a warning. Technically, the six types of behavior must be mastered and actualized by the teacher in teaching behavior in the classroom. It is necessary in order to be able to create a conducive classroom climate (Salabi, 2016).

In table 4, the analysis of the classroom management indicators showed that class management is categorized as good and has the highest percentage of teachers wearing polite, clean, and tidy clothes. In the learning process, the teacher is the center of student attention so that all movements and what he wears will attract the attention of students. Teachers who wear polite, clean, and neat clothes will emit a good image of the teacher's personality. It is not expected that the clothes worn by the teacher attract students' attention more than the material presented. So if a student is already interested in the teacher, either from the way the teacher dresses or the teacher's personality, then students will have a desire to be happy to follow the teacher's learning.

\section{Learning Motivation}

Learning motivation is a psychological factor that is non-intellectual but can improve intellectual abilities. The typical role of motivation is passion or enthusiasm for learning. Strongly motivated students will have much energy to follow the learning activities (Marisa, 2019). Learning motivation is important for students and teachers. The importance of learning motivation is, a) to make students aware of the students' position at the beginning of learning, learning processes, and outcomes, b) to inform about the strength of learning efforts compared to peers, c) to direct learning activities, d) to raise the spirit of learning, e) to make awareness about the existence of a learning journey. Learning motivation is also important for teachers to know because knowledge and understanding of learning motivation are useful for teachers to, a) arouse, improve and maintain students' enthusiasm for learning to succeed, b) know and understand students' motivation in various classes, there are who are indifferent, some do not get attention, c) increase and make teachers aware of choosing one of the various roles such as advisor, facilitator, instructor, motivator, or gift-giver (Rumhadi, 2017).

Based on table 8 , the analysis of the motivation indicators showed that students have high motivation and a high percentage value towards their hopes and ambitions for the future. Hopes are based on the belief that people are influenced by how they feel about the outcome of their actions. The ambitions and hopes will motivate a person because he achieves those hopes and ambitions. In terms of learning, the ambitions of students will make them eager to learn. It is done to achieve these ambitions. 


\section{The Effect of Classroom Management on Students' Mathematics Learning Motivation}

Teachers play an important role in stimulating students' learning motivation. Teachers should be aware that there are students who are motivated to learn in every class, and some are not. So the teacher must understand and think of specific techniques to modify the student behavior. Efforts to develop student motivation can be made through classroom management. Classroom management is a process to develop a learning environment and physical interaction, motivate students to learn, and manage classes to facilitate and support the continuity of the teaching and learning process to improve the quality and achievement of students. The application of classroom management principles affects the emergence of student learning motivation. A conducive atmosphere encourages a sense of comfort for students so that students are motivated to participate in the learning process with pleasure (Pujiman et al., 2021).

Classroom management is an external factor that affects students' motivation to learn mathematics. Other factors that can influence student learning motivation are internal factors, including 1) hopes and ambitions, 2) students' abilities, 3) students' conditions, 4) students' psychological state including skills, intelligence, attitudes, perceptions, interests, and dynamic elements in learning (Cahyani et al., 2020).

The results of the percentage analysis of class management data and learning motivation found that the class management applied was sufficient and good. In this case, it could motivate students to learn mathematics in a high category - the theory stated by Jones and Jones that motivating students is a key aspect of effective classroom management. So, applying effective classroom management to existing indicators can increase students' motivation to learn mathematics.

Several studies examine classroom management and learning motivation, namely research conducted by Rizki \& Noviardilla (2021) and Sunardin (2020). The two studies only discussed the relationship between classroom management and learning motivation. While in this study, apart from looking at the relationship, also looked at how effective class management was on students' motivation to learn mathematics. The research of Rizki \& Noviardilla (2021) found that the teaching skills of teachers can raise students' enthusiasm and motivation. Sunardin's research found that student seating arrangements can motivate student learning. Meanwhile, in this study, what the researchers got was that in addition to the teacher's teaching skills and student seating arrangements, student learning motivation can also increase because the teacher creates order, discipline, comfort, safety, and decisions on regulations in carrying out the learning process, the words used, and teacher appearance.

\section{CONCLUSION}

Based on the regression significance, the alternative hypothesis was accepted and proven true, namely that class management had a significant effect on students' motivation to learn mathematics. In contrast, the null hypothesis was rejected. There was no significant effect of class management on students' motivation to learn mathematics. So it can be concluded that class management has a significant effect on students' mathematics learning motivation in the twelfth grade of natural science group at one of the senior high schools in West Sumatra, Indonesia, for the 2021/2022 academic year. So those students are motivated to learn mathematics. The researcher's suggestion for teachers is that it is expected that classroom management the teachers apply must be effective so that students have good learning motivation. The school is expected to 
evaluate the way teachers manage the class and always monitor students' motivation to learn mathematics. Then. The researcher's suggestion for the next researcher is to develop the subject of this research further.

\section{REFERENCES}

Astuti, A. (2019). Manajemen Kelas yang Efektif. Adaara: Jurnal Manajemen Pendidikan Islam, 9(2), 892-907.

Cahyani, A., Listiana, I. D., \& Larasati, S. P. D. (2020). Motivasi Belajar Siswa SMA pada Pembelajaran Daring di Masa Pandemi Covid-19. IQ (Ilmu Al-qur'an): Jurnal Pendidikan Islam, 3(01), 123-140.

Erwinsyah, A. (2017). Manajemen kelas dalam meningkatkan efektifitas proses belajar mengajar. TADBIR: Jurnal Manajemen Pendidikan Islam, 5(2), 87-105.

Rahma, U., \& Dara, Y. P. (2017). Psikologi Pendidikan: Aplikasi Teori di Indonesia. Malang: Universitas Brawijaya Press.

Haerena. (2016). Manajemen Pembelajaran Berbasis Standar Proses Pendidikan: Teori dan Aplikasinya. Yogyakarta: Media Akademi.

Haryani, S. (2020). Improved Class Management Ability in PBM Activities Through Clinical Supervision on Elementary School Teachers in the Classroom UPT PPK Jetis. Ideguru: Jurnal Karya Ilmiah Guru, 5(2), 91-97.

Hidayat, W., Jahari, J., \& Shyfa, C. N. (2020). Manajemen Kelas Dalam Meningkatkan Proses Pembelajaran Di Madrasah. Jurnal Pendidikan UNIGA, 14(1), 308-317.

Kurni, D. K., \& Susanto, R. (2018). Pengaruh keterampilan manajemen kelas terhadap kualitas proses pembelajaran di sekolah dasar pada kelas tinggi. Jurnal Ilmiah Pendidikan Guru Sekolah Dasar, 2(01), 39-45.

Mahmud, S., \& Idham, M. (2017). Strategi Belajar Mengajar. Banda Aceh: Syiah Kuala University Press.

Marisa, S. (2019). Pengaruh Motivasi dalam Pembelajaran Siswa Upaya Mengatasi Permaslahan Belajar. Jurnal Taushiah, 9(2), 20-27.

Nasrah, N., \& Muafiah, A. M. A. (2020). Analisis Motivasi Belajar Dan Hasil Belajar Daring Mahasiswa Pada Masa Pandemik Covid-19. JRPD (Jumal Riset Pendidikan Dasar), 3(2), $207-$ 213.

Siagian, M. D. (2017). Pembelajaran Matematika dalam Persfektif Konstruktivisme. Jurnal pendidikan islam dan teknologi pendidikan, 7(2), 61-73.

Nugraha, M. (2018). Manajemen Kelas Dalam Meningkatkan Proses Pembelajaran. Tarbawi: Jurnal Keilmuan Manajemen Pendidikan, 4(01), 27-44.

Pratiwi, G., Waluyati, S. A., \& Kurnisar. (2019). Upaya Guru Dalam Meningkatkan Motivasi Belajar Siswa Pada Mata Pelajaran PPKn di SMP Negeri 13 Palembang. Jurnal Bhinneka Tunggal Ika, 6(1), 54-63. 
Pujiman, P., Rukayah, R., \& Matsuri, M. (2021). Penerapan prinsip manajemen kelas dan pengaruhnya terhadap motivasi belajar siswa di sekolah dasar. JPI (Jumal Pendidikan Indonesia): Jurnal Ilmiah Pendidikan, 7(2), 124-128.

Rizki, M., \& Noviardilla, I. (2021). Kajian Literatur Tentang Hubungan Pengelolaan Kelas dengan Motivasi Belajar Siswa Sekolah Dasar. Jurnal Pendidikan Tambusai, 5(1), 267-271.

Rumhadi, T. (2017). Urgensi Motivasi Dalam Proses Pembelajaran. Inovasi-jurnal Diklat Keagamaan, 11(1), 33-41.

Salabi, A. (2016). Konsepsi Manajemen Kelas: Masalah dan Pemecahannya. Jurnal Tarbiyah Jurnal Ilmiah Pendidikan), 5(2), 69-78.

Setiaji, C. A. (2019). Strategi Pembelajaran Inovatif. Yogyakarta: Graha Ilmu.

Sidik, Z., \& Sobandi, A. (2018). Upaya meningkatkan motivasi belajar siswa melalui kemampuan komunikasi interpersonal guru. Jurnal Pendidikan Manajemen Perkantoran (JPManper), 3(2), 190 198.

Suharni \& Purwanti. (2018). Upaya Meningkatkan Motivasi Belajar Siswa. G-COUNS: Bimbingan dan Konseling, 3(1), 131-145.

Sunardin, S. (2020). Hubungan antara Pengelolaan Kelas dengan Motivasi Belajar Siswa pada Mata Pelajaran IPS Kelas III SDN Blukbuk 1 Kabupaten Tangerang. Syntax Idea, 2(3), 78-83.

Sunu, I. G., \& Arya, G. K. (2015). Manajemen Kelas: Aplikasinya dalam Proses Pembelajaran di Pendidikan Formal. Yogyakarta: Media Akademi.

Susanti, L. (2019). Strategi Pembelajaran Berbasis Mitivasi. Elex Media Komputindo. 